\title{
Tracer Study of Graduates in Doctor of Philosophy in Educational Planning and Management: University of Science and Technology of Southern Philippines (USTP)
}

\author{
Duque A. Caguindangan ${ }^{1}$, Lita F. Base ${ }^{2}$, Renato L. Base ${ }^{3}$
}

\begin{abstract}
This study was conducted to find out how the Ph.D. graduates in Educational Planning and Administration have been doing in their professional life after they have completed their doctoral studies. Specifically, this study aimed to obtain graduates' assessment of the graduate school program and the effect of obtaining the degree in their professional life. The research utilized the descriptive survey method, with a sample size of $42 \mathrm{PhD}$-Educational Planning and Management graduates from the school year 2011-2020. The findings have shown that the majority of the participants are female, working in the public school and teaching at the basic education level. On the other hand, the majority were promoted after 3 years or longer after obtaining the degree, and most are promoted from a teacher rank to an administrative position, which resulted in a higher salary grade. Likewise, all the graduates that were interviewed were promoted and none was not promoted. Hence, the Ph.D. graduates consider Ph.D. in Educational Planning and Management as a program relevant to the time, as "very high", the quality of its program offering as "high", while the responsiveness of the curriculum to industry requirements was "moderate". In addition, the Ph.D. graduates' attainment of USTP Institutional Graduate Attributes ranges from "moderately attained" to "very greatly attained". Moreover, the personal gains derived from pursuing the degree were as follows: strong community engagement, promotion, self-confidence, higher self-esteem, and confidence in dealing with personal problems. Further, the degree had enhanced the participants' knowledge and skills in their teaching and managerial functions.
\end{abstract}

Keywords: Doctor of Philosophy in Educational Planning and Management; USTP; graduate school; tracer study

\footnotetext{
${ }^{1}$ Working as Elementary School Principal in Cagayan De Oro City ,DepEd Region 10

2 Working supervisor in the Department of Education (DepEd), Region 10

${ }^{3}$ Faculty, Department of Educational Planning and Administration, University of Science and

Technology of Southern Philippines (USTP), Cagayan de Oro City, Philippines. Email:

renato.base@ustp.edu.ph.
} 


\section{INTRODUCTION}

It has been proven that education leads to a change in behavior, enhances one's innate capacities as well as the basis toward a successful professional life (Qureshi, 2017). As a result, education helps the individual to further progress and develop its emotional, intellectual, and even spiritual (Khan, 2017) dimensions. On this basis, it is reasonable to aver that education can equip the individual with capacities crucial in addressing the challenges in the workplace in particular, and that of life in general. It is on this consideration that we revisited the old curriculum and crafted a new curriculum in educational planning and administration. Nonetheless, the new curriculum was still anchored on the strength of the old curriculum. In so doing, any innovations being introduced in the new curriculum, its learning outcomes, and learning activities/strategies are anchored on the existing strength of the old one. Consequently, this tracer study was conducted to ascertain the overall responsiveness of the old curriculum in light of the demands of the present times. Hence, this study.

Given the fact that the world is now becoming more integrated through globalization and the ASEAN integration, quality education is now a necessity. Thus, for an educational program to respond to global, regional, and local challenges, its educational curriculum must be able to respond to these challenges. Therefore, the curriculum must also be updated and enhanced. One of the approaches in which educational programs become responsive is to revise it to make it oriented towards innovations, new ways of thinking, and doing of things. In a word, it should promote to its students an attitude of thinking outside the box, so to speak so that the curricular program itself will become more responsive to the societal changes occurring in the present as well as in the future. Therefore, it is imperative that the curricular program, which in this case is the graduate program (both Master and Ph.D. level) in Educational Planning and Management, must be revisited and assessed at a regular interval.

Corollary to this re-visitation and evaluation is the conduct of a tracer study as one means of ascertaining the responsiveness of the curriculum so that a more objective benchmark can be garnered as to whether the said curriculum is still responsive to the demands and challenges of the times. At stake in the assessment of the curriculum, is the reputation of the program and the educational institution that hosted the said program, which in this case is the University of Science and Technology of Southern Philippines (USTP). It had been pointed out that the alumni are supposed to bring encouragement, strength, and expansion to an institution of higher learning as well as reflect the reputations and progress of that institution (Faize, Ahmed, and Jabeen, 2015). For they serve as the concrete example of the curricular program's effectiveness in terms of employment and positions. Consequently, they are a good source of information as to the program's relevance to the labor market.

With this in mind, the Department of Educational Planning and Management (presently Department of Educational Planning and Administration) conducted this graduate tracer study to generate empirical evidence that can provide crucial information in evaluating the effectiveness of the department's curricular offering, and also to make such information the basis to further improve the old program's curriculum (cf. Woya, 2019). The information gathered served as the basis for determining the quality, and the extent of functionality of the services being delivered to the graduates of the said program. The rationale for this tracer study is to collect data on the employment situation of recent graduates to obtain indicators for their professional performance (cf. Teichler, 1998). Through this study, the data could be utilized to provide insights into the relevance and appropriateness of the study conditions, services, and the two programs under the Department. In short, it provides an insight into the quality of the graduate product (Teichler 2011, Schomburg and Teichler 2011, 
Herrmann 2010). Furthermore, the Department will utilize the said data in drawing recommendations from the perspective of the graduates. It must be underscored that their perspective is crucial for evolving a new practice, and has potential when it comes to policy change as to the direction the Department should be taking in the coming years (cf. Teichler, 2003; OECD, 1999). Finally, it enables the Department to make informed and evidence-based decisions about improvements in teaching and pedagogy in the two graduates programs under its patronage (cf. Schomburg, 2011).

In view of this, the Department of Educational Planning and Administration of the University of Science and Technology of Southern Philippines (USTP), has been offering quality programs for both master and doctorate students in educational planning and management. Consequently, this tracer study served as the basis that informed the revision of the old curriculum in Master of Educational Planning and Management into Master of Science in Educational Planning and Administration, and the Doctor of Philosophy in Educational Planning and Management into and Doctor of Philosophy in Educational Planning and Administration. With this in mind, it is then the purpose of this study to conduct a follow-up of its Ph.D. graduates in terms of productivity to ensure the effectiveness and relevance of this program relative to the challenges facing our society.

\section{Statement of the Problem}

The primary objective of this study, therefore, was to come up with pertinent data as a basis in the assessment of the relevance and effectiveness of the Ph.D. graduate's in the Educational Planning and Management program of USTP CDO-Campus.

In line with this, the study attempted to answer the following:

1. What is the profile of the participants in terms of:

1.1 Gender

1.2 The type of school i.e. public or private

1.3 The institution's level of education (in which the graduates are connected), i.e. basic or higher education

1.4 Their promotion details, such as

1.4.1 Promotion status

1.4.2 Waiting period before their promotion

1.4.3 Position

1.4.5 Salary

2. What are the graduate's community engagements after having obtained their Ph.D. degree?

3. What are the graduate's assessments on the extent to which they achieved the USTP Institutional Graduates Attributes?

4. What are the graduate's perceptions of the Ph.D. in Educational Planning and Management in terms of relevance, quality of program offerings, and responsiveness of the curriculum to industry requirements?

5. Participants' perception of the contributions of getting a degree in Ph.D. Educational Planning and Management to the Enhancement of their personal and professional lives?

6. What are the graduate's suggestions to enhance further the doctorate program and its implementation?

\section{Scope and Limitation of Study}

This study limits itself to the assessment of some pertinent demographics of our doctorate graduates in Educational Planning and Management. The study further delimits itself in terms of their promotion rate and 
status, degree of satisfaction concerning the changes that have occurred in their lives as a result of their attainment of the Ph.D. degree, and some recommendations that can be utilized in the improvement of the Department's master and doctoral program in Educational Planning and Management.

Due to limitations imposed during the pandemic, the aim of getting all those that graduated per school year was not realized.

\section{METHODOLOGY}

Research Design

A mixed-method research design was employed to obtain pertinent data on graduates' personal and professional profiles and their school experiences based upon interviews and surveys. These data served as the basis on which the assessment, as stated in the objective of this study proceeded.

\section{Participants of the Study}

The study participants included 42 graduates of the Ph.D. in Educational Planning and Management from school years 2011-2020. These 42 graduates served as the study's respondents. The distribution of respondents per school year is found in Table 1 .

\begin{tabular}{|c|c|c|}
\hline \multicolumn{3}{|c|}{ Table 1. Frequency and Percentage Distributions of Ph.D. Graduates Respondents by Academic Year. } \\
\hline Academic Year & Frequency & Percentage \\
\hline $2019-2020$ & 6 & 14.3 \\
\hline $2018-2019$ & 4 & 9.5 \\
\hline $2017-2018$ & 4 & 9.5 \\
\hline $2016-2017$ & 5 & 11.9 \\
\hline $2015-2016$ & 4 & 9.5 \\
\hline $2014-2015$ & 3 & 7.1 \\
\hline $2013-2014$ & 4 & 9.5 \\
\hline $2012-2013$ & 4 & 9.5 \\
\hline $2011-2012$ & 4 & 9.5 \\
\hline $2010-2011$ & 4 & 9.5 \\
\hline Total & 42 & 100.0 \\
\hline
\end{tabular}

\section{Instrumentation}

The instrument used is a researcher-made questionnaire in a 5-points Likert-type scale that captures all the relevant data for the questions that were being posited in the Statement of the Problem. This tool has three parts. Part I on the demographic profile of the Ph.D. graduates. Part II deals with the University's Institutional Graduate Attributes, the relevance, quality, and responsiveness of the program. Part III and IV are open-ended questions to elicit information on the graduate's perception concerning the contribution of having a Ph.D. degree in their personal and professional lives as well as their suggestions for further enhancement of the Department's Ph.D. program.

\section{Data Analysis}

The following statistics were used in the treatment of the quantitative data such as frequency count, 
percentages, and the mean. The latter serves as a basis in coming up with a descriptive interpretation of the respondent's Likert-type scale responses. As a way of determining the university's institutional graduates' attributes. The means were then interpreted using the following descriptive interpretation particularly concerning the extent of attainment of the institutional graduate's attributes:

$\begin{array}{lll}\text { Scale } & \text { Scores } & \text { Descriptive Interpretation } \\ 5 & 4.20-5.00 & \text { Very Great attained } \\ 4 & 3.40-4.19 & \text { Greatly attained } \\ 3 & 2.60-3.39 & \text { Moderately attained } \\ 2 & 1.80-2.59 & \text { Low attained } \\ 1 & 1.00-1.79 & \text { Very Low attained }\end{array}$

A similar Likert-type scale was also crafted to ascertain the level of the overall significance of the program in terms of its relevance, quality, and responsiveness. The responses of the respondents were then interpreted in this manner:

$\begin{array}{lll}\text { Scale } & \text { Scores } & \text { Descriptive Interpretation } \\ 5 & 4.20-5.00 & \text { Very high } \\ 4 & 3.40-4.19 & \text { High } \\ 3 & 2.60-3.39 & \text { Average } \\ 2 & 1.80-2.59 & \text { Low } \\ 1 & 1.00-1.79 & \text { Very low }\end{array}$

On the other hand, in treating the qualitative data that were collected through open-ended questions, thematic analysis was used to organize the participant's responses.

\section{RESULTS AND DISCUSSION}

Profile of the Respondents

As shown in Table 2, when the respondents were grouped according to gender, it was found out that $54.8 \%$ of educational planning and management graduates were female compared to $45.2 \%$ male graduates.

Table 2. Frequency and Percentage Distributions of Ph.D. Graduates Students Respondents, by Gender.

\begin{tabular}{|c|c|c|}
\hline Gender & F & $\%$ \\
\hline Male & 19 & 45.2 \\
\hline Female & 23 & 54.8 \\
\hline Total & 42 & 100.0 \\
\hline
\end{tabular}

Profile of the Respondents by Type School and by Type of Education

In Table 3, when respondent's demographics such as type of school and type of education were crosstabulated, it was found out that $69 \%$ of graduates that work in the public school were connected in the basic education as compared to $53.8 \%$ of graduate respondents that work in private school and connected in the basic education. On the other hand, $31 \%$ of graduates that work in public school were connected in higher education institutions as compared to $46.2 \%$ of graduates that came from the private school and connected in higher education. 


\begin{tabular}{|c|c|c|c|c|}
\hline \multirow{3}{*}{ Type of Education } & \multicolumn{4}{|c|}{ Type of School } \\
\hline & \multicolumn{2}{|c|}{ Public } & \multicolumn{2}{|c|}{ Private } \\
\hline & $\mathrm{F}$ & $\%$ & $\mathrm{~F}$ & $\%$ \\
\hline Basic Education & 20 & 69.0 & 7 & 53.8 \\
\hline Higher Education & 9 & 31.0 & 6 & 46.2 \\
\hline Total & 29 & 100.0 & 11 & 100 \\
\hline
\end{tabular}

Profile of the Respondents by Promotion Details

In Table 4 below, when respondents' promotion details were grouped according to Promotion Status, it was found out that $100 \%$ of graduates have been promoted at various periods after they completed a doctorate in educational planning and administration.

On the other hand, when those who were promoted were grouped according to the waiting period before their promotion, it was found out that $33.3 \%$ waited after 3 years or longer as compared to $28.6 \%$ that respectively waited after 2 years to less than 3 years, and after 1 year to less than 2 years. On one hand, $9.5 \%$ of those that were promoted have waited after 1 year to less than 2 years.

Lastly, when those promoted were grouped according to promoted position, it was found out that $38.1 \%$ were promoted from Teacher Rank to Administrative Position as compared to $35.7 \%, 14.3 \%$, and $11.9 \%$ who were respectively promoted from Higher Level Rank (Administrative Position), from Higher Level Rank (Within Teacher Level Promotion), and those with No Change in position.

Table 4. Frequency and Percentage Distributions of Graduates Respondents Promotion Details, by Promotion Status, by Waiting Period Before Promotion, and by Promoted Positions.

\begin{tabular}{|c|c|c|}
\hline \multicolumn{3}{|c|}{ Promotion Details } \\
\hline Promotion Status & $\mathrm{F}$ & $\%$ \\
\hline Promoted & 42 & 100 \\
\hline Not promoted & 0 & 0 \\
\hline Total & 42 & 100 \\
\hline Waiting Period Before Promotion & $\mathrm{F}$ & $\%$ \\
\hline After 3 years or longer & 14 & 33.3 \\
\hline After 2 years to less than 3 years & 12 & 28.6 \\
\hline After 1 year to less than 2 years & 12 & 28.6 \\
\hline After 1 year to less than 2 years & 4 & 9.5 \\
\hline Total & 42 & 100 \\
\hline Promoted Position & $\mathrm{F}$ & $\%$ \\
\hline No Change in Position & 5 & 11.9 \\
\hline
\end{tabular}


Table 4. Frequency and Percentage Distributions of Graduates Respondents Promotion Details, by Promotion Status, by Waiting Period Before Promotion, and by Promoted Positions.

\begin{tabular}{|c|c|c|}
\hline \multicolumn{3}{|c|}{ Promotion Details } \\
\hline Higher Level Rank (Administrative Position) & 15 & 35.7 \\
\hline Teacher Rank to Administrative Position & 16 & 38.1 \\
\hline Higher Level Rank (Within Teacher Level Positon) & 6 & 14.3 \\
\hline Total & 42 & 100 \\
\hline
\end{tabular}

Profile of the Respondents by Salary Range Before and After Promotion

In Table 5 below, when respondent's salaries were grouped according to Promotion Status, it was found out that $4.8 \%$ of graduates before their promotion had a salary that range between $\mathrm{P} 66,000$-and above, and those with such a salary range have increased to $6.8 \%$ after some of these graduates got promoted to this salary range.

Similarly, $4.8 \%$ of graduates before they completed their promotion had a salary range between P61,00065,999 , and those with such a salary range have increased to $6.8 \%$ after some of these graduates were promoted to this salary range.

Moving on, there were $21.4 \%$ of graduates had a salary range between $\mathrm{P} 56,000-60,000$ before promotion while those with such a salary range have decreased to $15.9 \%$ after some of these graduates with such pay scale moved to a higher pay grade. This decrease therefore may imply that, so far during the conduct of this research, no graduate was promoted to this level of pay grade.

On the other hand, $23.8 \%$ of graduates had a salary range between $\mathrm{P} 51,000-55,999$ before their promotion while those with such a salary range have increased to $27.3 \%$ after some of these graduates were promoted to this pay grade.

Furthermore, $4.8 \%$ of graduates had a salary range between $\mathrm{P} 46,000-50,999$ before their promotion while those with such a salary range have increased to $18.2 \%$ after some of these graduates were promoted to this pay grade.

On one hand, $26.2 \%$ of graduates had a salary range between $\mathrm{P} 41,000-45,999$ before promotion while those with such salary range have decreased to $11.4 \%$ after some of these graduates with such pay scale moved to a higher pay grade. This decrease therefore may imply that, so far during the conduct of this research, no graduate was promoted to this level of pay grade.

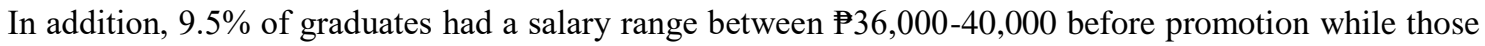
with such salary range have increased to $13.6 \%$ after some of these graduates were promoted to this pay grade. Lastly, $4.8 \%$ of graduates had a salary range between $\mathrm{P} 31,000-35,999$ before promotion while those with such salary range have decreased to nil after some of these graduates with such a pay scale moved to a higher pay grade. This decrease therefore may imply that, so far during this study, no graduate had remained within this pay grade. 
Table 5. Frequency and Percentage Distribution of Graduates Respondents, by Salary Range, by Salary Before Promotion, and by Salary After Promotion.

\begin{tabular}{|l|c|c|c|c|}
\hline \multirow{2}{*}{$\begin{array}{c}\text { Salary Range } \\
(\boldsymbol{P})\end{array}$} & Salary Before Promotion & \multicolumn{3}{c|}{ Current Salary } \\
\cline { 2 - 5 } & $\mathrm{F}$ & $\%$ & $\mathrm{~F}$ & $\%$ \\
\hline $66,000.00$ and above & 2 & 4.8 & 3 & 6.8 \\
\hline $61,000.00-65,999.00$ & 2 & 4.8 & 3 & 6.8 \\
\hline $56,000.00-60,000.00$ & 9 & 21.4 & 7 & 15.9 \\
\hline $51,000.00-55,999.00$ & 10 & 23.8 & 12 & 27.3 \\
\hline $46,000.00-50,999.00$ & 2 & 4.8 & 8 & 18.2 \\
\hline $41,000.00-45,999.00$ & 11 & 26.2 & 5 & 11.4 \\
\hline $36,000.00-40,999.00$ & 4 & 9.5 & 6 & 13.6 \\
\hline $31,000.00-35,999.00$ & 2 & 4.8 & 0 & 0.0 \\
\hline Total & 42 & 100 & 44 & 100 \\
\hline
\end{tabular}

Respondents Extent of Attainment of USTP Institutional Graduate Attributes

The six institutional graduate attributes of USTP undergirded all the curricular offerings of the University.

As shown in Table 6, the six (6) institutional graduates' attributes of USTP are being reflected. We found out that of the six graduate attributes the graduates in the educational planning and management doctorate program have moderately attained innovative thinking and critical thinking. On the other hand, they have greatly attained the attributes of resilience and communication skills while very greatly attaining the attributes of empathy, and teamwork, and collaboration.

Table 6. Weighted Mean Distributions with Interpretation on Ph.D. Educational Planning and Administration's Graduates Relative to the Attainment of USTP's Institutional Graduates Attributes.

\begin{tabular}{|c|c|l|c|c|}
\hline Code & $\begin{array}{c}\text { Graduate } \\
\text { Attributes }\end{array}$ & \multicolumn{1}{|c|}{ Description } & Mean & Interpretation \\
\hline $\begin{array}{c}\text { Institutional } \\
\text { Graduate } \\
\text { Attribute }-1\end{array}$ & $\begin{array}{c}\text { Innovative } \\
\text { Thinking }\end{array}$ & $\begin{array}{l}\text { A USTP graduate generates new ideas or } \\
\text { new ways of approaching things to } \\
\text { create possibilities and opportunities. }\end{array}$ & 3.19 & $\begin{array}{c}\text { Moderately } \\
\text { attained }\end{array}$ \\
\hline $\begin{array}{c}\text { Institutional } \\
\text { Graduate } \\
\text { Attribute }-2\end{array}$ & Critical Thinking & $\begin{array}{l}\text { A USTP graduate objectively examines } \\
\text { a situation by gathering information } \\
\text { from all possible sources and evaluates } \\
\text { both the tangible and intangible aspects, } \\
\text { as well as the implications of any course } \\
\text { of action. }\end{array}$ & 3.31 & $\begin{array}{c}\text { Moderately } \\
\text { attained }\end{array}$ \\
\hline $\begin{array}{c}\text { Institutional } \\
\text { Graduate } \\
\text { Attribute }-3\end{array}$ & Resilience & $\begin{array}{l}\text { A USTP graduate thrives, grows, and } \\
\text { develops competence in the face of } \\
\text { adverse circumstances }\end{array}$ & 4.03 & $\begin{array}{c}\text { Greatly } \\
\text { attained }\end{array}$ \\
\hline $\begin{array}{c}\text { Institutional } \\
\text { Graduate } \\
\text { Attribute }-4\end{array}$ & Empathy & $\begin{array}{l}\text { A USTP graduate identifies and } \\
\text { understands another's situation and } \\
\text { feelings allowing for caring }\end{array}$ & 4.42 & Very greatly \\
attained
\end{tabular}


Table 6. Weighted Mean Distributions with Interpretation on Ph.D. Educational Planning and Administration's Graduates Relative to the Attainment of USTP's Institutional Graduates Attributes.

\begin{tabular}{|c|c|c|c|c|}
\hline Code & $\begin{array}{l}\text { Graduate } \\
\text { Attributes }\end{array}$ & Description & Mean & Interpretation \\
\hline $\begin{array}{l}\text { Institutional } \\
\text { Graduate } \\
\text { Attribute - } 5\end{array}$ & $\begin{array}{l}\text { Teamwork and } \\
\text { Collaboration }\end{array}$ & $\begin{array}{l}\text { A USTP graduate works effectively and } \\
\text { respectfully with diverse teams. This } \\
\text { includes assuming shared responsibility } \\
\text { for collaborative work and valuing the } \\
\text { individual }\end{array}$ & 4.75 & $\begin{array}{l}\text { Very greatly } \\
\text { attained }\end{array}$ \\
\hline $\begin{array}{l}\text { Institutional } \\
\text { Graduate } \\
\text { Attribute - } 6\end{array}$ & $\begin{array}{c}\text { Communication } \\
\text { Skills }\end{array}$ & $\begin{array}{l}\text { A USTP graduate presents and } \\
\text { articulates views, thoughts, and ideas by } \\
\text { effectively using oral, written, } \\
\text { multimedia, and nonverbal } \\
\text { communication skills in a variety of } \\
\text { forms and contexts. }\end{array}$ & 3.81 & $\begin{array}{l}\text { Greatly } \\
\text { attained }\end{array}$ \\
\hline
\end{tabular}

Respondents Perceptions of the Program's Relevance to the Time, Quality of Program Offerings, and Responsiveness of the Curriculum to Industry Requirements

The study also asked the Ph.D. graduate respondents as to what they thought about the offering of educational planning and management at USTP in terms of the following indicators, namely, the relevance of the program to the present time, the quality of the program offers, and the responsiveness of the curriculum to industry requirements. The result is shown in Table 7.

As depicted in Table 7, it was the area of the relevance of the program that garnered a mean of 4.75 that can be interpreted to mean that the curricular offering is indeed very relevant. On the quality of the program, the graduates rated it as being high with a corresponding mean of 3.53. Lastly, on the responsiveness of the curriculum to industry requirements, the graduates rated it as moderate with a mean score of 2.89 .

Table 7. Weighted Mean Distributions with Interpretation on Ph.D. Educational Planning and Administration's Graduates Relevance, Quality of Curricular offering, and Responsiveness to Industry

\begin{tabular}{|l|c|c|}
\hline \multicolumn{1}{|c|}{ Indicators } & Mean & Interpretation \\
\hline 1. Relevance of the program to the time & 4.75 & Very High \\
\hline 2. Quality of program offering & 3.53 & High \\
\hline 3. Responsiveness of the curriculum to industry requirements & 2.89 & Moderate \\
\hline
\end{tabular}

Graduates Engagements in the Community after Getting their Ph.D. Degree

After getting their Ph.D. degree in educational planning and management, our graduates have been actively engaged in their community activities, particularly in their active participation in the following initiatives of the barangay: symposia on health and wellness, education, and green and clean program. Our graduates got involved and likewise initiated socio-civic activities like fund-raising and giving of relief goods. Given this, 87 percent of our graduates are engaged in public services such as counselors for students' parents and out of the school of youths. The graduates also assisted in the barangay drives for backyard gardening, environmental stewardship, community projects, anti-drug campaign, maintenance of peace, and order. 
Graduates' Perceptions of the Gains of having a Degree in Ph.D. to their Personal and Professional Life

\section{A. Personal Gains}

In terms of the gains of having a Ph.D. degree. Accordingly, it contributed to their personal life, it was underscored by the graduates that it facilitated their promotion, helped improve their relationship with colleagues and administrators, boosted their self-esteem and self-confidence, gained respect from their peers, and gave them better perspectives in handling life's situations by being more resilient, and confidence in facing their problems. The degree has endowed them with high ethical values and a deep sense of duty as public servants.

\section{B. Professional Gains}

In terms of the gains of having a Ph.D. degree in educational planning and management, the graduates underlined that it enhanced their knowledge and skills in their teaching and managerial functions. They also claimed that it boosted their present information relative to the teaching profession, protocols and fundamentals of a public servant, specialized knowledge for career advancement, in-depth understanding of the profession, and educational management. By having such a degree, they gained trust and confidence in public speaking, and become a competent leader since it boosted their leadership and governance skills, and their competitiveness. In addition, they also learned how to deal effectively with stakeholders and understand broader aspects of school governance. In having the $\mathrm{Ph} . \mathrm{D}$. degree, they were tapped as chairperson of committee training, facilitator in group discussions and workshops, and collaborators with internal and external stakeholders. In addition, having such a Ph.D. degree has enhanced their decision-making skills, helped them inspire others, made them more professional in words and actions, and endowed them with good management and organizational skills.

Graduates Suggestions to Improve Further the Educational Planning and Management Curriculum

The following were the recommendations offered by the graduates to improve further the Doctor of Philosophy in Educational Planning and Administration. These were as follows:

First, master's and doctorate students should be oriented and as well as able to put into practice the, while still being a student, the institutional graduate's attributes of USTP.

Second, open more opportunities for students to widen as well as to reinforce their sense of community service.

Third, blended learning should be sustained to meet the needs of local and international students.

Fourth, strengthen and sustain the practice of research-based projects.

Fifth, revisit and revise the curriculum with stakeholders' participation so that it will be more responsive to the demands of the time.

Sixth, institutionalize the inclusion of professors from outside the country to become adjunct professors of the program.

Seventh, Conduct lecture series relative to pertinent topics, issues, and challenges facing the global education system as well as our local education system to make masters and Ph.D. students updated with what 
is currently happening within and outside the Philippines.

\section{CONCLUSION}

Therefore, based on the findings, we reached the following conclusions. The Ph.D. in Educational Planning and Management program of the College of Science and Technology Education in USTP CDO Campus indeed has contributed to the enhancement of our graduates in both their personal and professional lives. However, given that our alumni assessed the quality of program offering and its responsiveness to industry requirements as merely high and moderate, respectively; and, also taking into consideration the recommendations of our alumni to revisit and revise the program, we, therefore, find such recommendation as appropriate. Hence, it must be acted accordingly. Given this recommendation from our alumni, the Department of Educational Planning and Management has undertaken the review and revision of its curriculum.

\section{RECOMMENDATIONS}

Because of the findings, the following recommendations are drawn. To conduct a review of the educational planning and management curriculum in response to the recommendations of our alumni to make the quality and responsiveness of the program very high. Since the last time, the program was revisited and reviewed was more or less ten years ago.

\section{BIBLIOGRAPHY}

Ashenafi Abate Woya, "Employability among Statistics Graduates: Graduates" Attributes, Competence, and Quality of Education", Education Research International, vol. 2019, Article ID 7285491, 7 pages, 2019. https://doi.org/10.1155/2019/7285491

Herrmann, D., Dilger, B. and M. Junghanns. (2010). Specialized Questionnaires in Graduate Tracer Studies; Demand, Development, and Back Channeling Results. Koln: University of Cologne. Khan, A.

(2017). Is education the key to a successful future? Retrieved from: https://www.jagranjosh.com/articles/education-is-the-key-to-future-success-or-not-503914512-1

Khan, A. (2017). Is education the key to a successful future? Retrieved from: https://www.jagranjosh.com/articles/education-is-the-key-to-future-success-or-not1503914512-1

Qureshi, T. (2017). Is education the key to a successful future? Retrieved at https://www.jagranjosh.com/articles/is-education-the-key-to-a-successful-future-1498733181-1

Schomburg, H. \&Teichler, U. (2011).Employability and Mobility of Bachelor Graduates in Europe: Key Results of the Bologna Process

Shakil, A.F., Faizi, W.U.N., Ahmed, S.M., \&Jabeen, F. (2015). A Critical Study Of The Subject Of Education At Graduate Level In Karachi. European Journal of Educational Research, 4(2), 81-89. https://doi.org/10.12973/eu-jer.4.2.81

Teichler U. (1998). "The Transition from Higher Education to Employment in Europe”, Higher Education in Europe, Vol. XXIII, No. 4.

Teichler U. (2003). "The Future of Higher Education and the Future of Higher Education research", Tertiary Education and Management, Vol. 9: pp. 171-185.

Teichler U. (2011). Lessons to be learned from Graduates: Interpretation of the Results of Graduate Surveys. Kassel: INCHER-Kassel.

Woya, A. (2019). Employability among Statistics Graduates: Graduates' Attributes Competence, and Quality of Education, Education Research International, p.7. https://doi.org/10.1155/2019/7285491 